
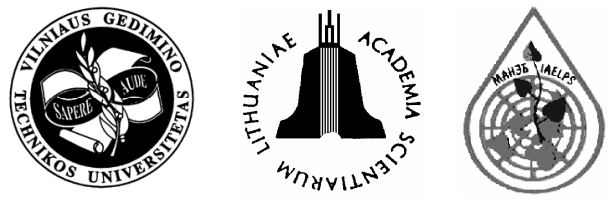

\title{
EFFICIENCY OF INERTIAL PRECIPITATION OF SUSPENDED PARTICLES IN HIGH-SPEED FIBROUS FILTERS
}

\author{
Arnold Waldberg ${ }^{1}$, Sergej Safonov ${ }^{2}$ \\ ${ }^{1,2}$ Moscow State University of Environmental Engineering, \\ ${ }^{2}$ JSC “NIIOGAZ” Staraya Basmannaya, 21/4, 105066 Moscow, Russia \\ ${ }^{1}$ E-mail: waldberg@inbox.ru
}

Submitted 18 Feb 2007; accepted 5 Apr 2007

\begin{abstract}
The paper gives theoretic analysis and results of experimental investigation of suspended particle collecting in high-speed fibrous mist collectors. A dominating role of inertial mechanism of suspended particle precipitation in highspeed mist collectors was determined and a method of calculation of their efficiency by means of probability integral was proposed. Applicability of physical analogy method to deduction of dependency determining values of $\mathrm{d}_{50}$ (diameter of particles collected in an apparatus under given technological mode of its operation with the efficiency of $50 \%$ ) on the basis of experimental data is shown. Experimental assembly used for research, testing techniques and result estimating methods are described. Investigation results allowed achieving an improved formula for calculating the value of $\mathrm{d}_{50}$ depending on hydraulic resistance of apparatus and density of collected particles.
\end{abstract}

Keywords: fibrous mist collector, auto-model mode, efficiency of inertial precipitation.

\section{Introduction}

Efficiency of precipitation of suspended particles in any type of dust extractor could be represented as a function of dimensionless precipitation parameters - criteria $[1,2]$, each of them characterizing a respective precipitation mechanism, and Re criterion which determines hydrodynamic mode of work of apparatus. If there's a mechanism playing a major role in precipitation of particles in an extractor of specific type, the calculation of efficiency of apparatus $\eta$ should be made in the light of this most likely mechanism of precipitation, removing all others from functional dependence (they are negligible here).

This approach allows significant simplification of calculation methods for gas-cleaning equipment.

In the case of dominance of inertial precipitation mechanism a Stokes criterion has the highest influence on dust extractor efficiency (under specific hydrodynamic mode of its work) - it is formally expressed as follows:

$$
S t k=\frac{d_{p}^{2} \cdot \rho_{p} \cdot v}{18 \cdot \mu \cdot l}
$$

where

$d_{p}$ - diameter of suspended particles (drops), $\mu \mathrm{m}$; $\rho_{p}$ - density of suspended particles (drops), $\mathrm{kg} / \mathrm{m}^{3} ; v-$ speed of gas flow in active area of dust or mist extractor, $\mathrm{m} / \mathrm{s} ; \mu$ - dynamic viscosity of gases, Pa.s; $l$ - linear parameter, characterizing precipitation surface, $\mathrm{m}$.

According to the above, the efficiency of dust and mist extractor with dominating inertial mechanism of precipitation of suspended particles could be considered as criteria dependence:

$$
\eta=f(S t k, \operatorname{Re})
$$

\section{The purpose and subject of investigation}

High-speed mist collectors (with the speed of filtration exceeding $2 \ldots 3 \mathrm{~m} / \mathrm{s}$ ) are an example of equipment for suspended particle removal with dominating role of inertial mechanism - in contrast to low-speed filters precipitating suspended particles mostly because of diffusion and cohesion effect.

In high-speed filters gas flows around cylinders (fibers of filtering partition) with the speed varying from 2 to $10 \mathrm{~m} / \mathrm{s}$. Under hydrodynamic mode of operation, typical for high-speed mist collectors, $\operatorname{Re}=\frac{v \cdot l \cdot \rho_{g}}{\mu}$ (here 1 is equal to the diameter of fiber $\mathrm{d}_{\mathrm{F}}$ ) is in the range of values from 30 to $3 \cdot 10^{4}$ (Fig 1), that, under the condition of gas flowing over fibers (cylinders), corresponds to automodel area [1], and the value of coefficient of hydraulic resistance $\zeta$ becomes constant $(\zeta=$ const), i e there is a "degeneration" of Re criterion and falls out of criterion dependence.

This fact allows application of dependency like $\eta=f(S t k)$ to evaluation of efficiency of inertial precipitation of suspended drops on fiber (cylinder).

In sources [2-4] there are given dependencies that establish relations of efficiency of inertial precipitation of suspended particles on fibers with the value of the Stokes 


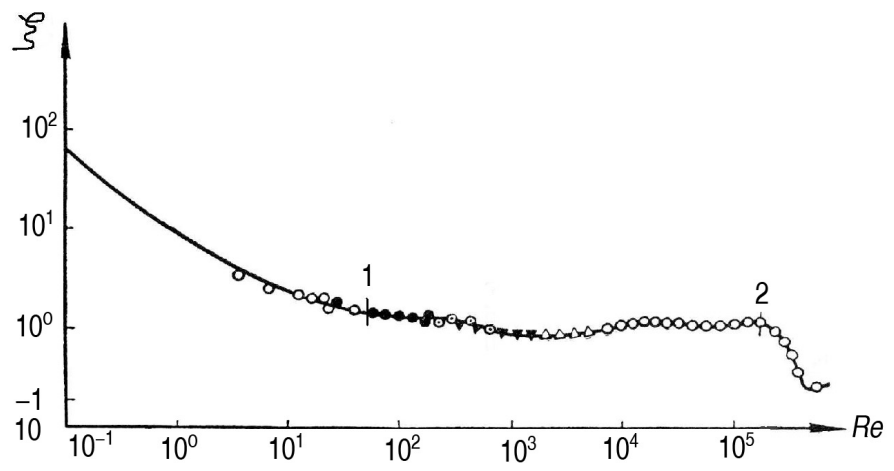

Fig 1. Dependence of coefficient $\zeta$ on Re criterion under gas flow over cylinder [1]: 1-2 - area of approximately constant values of $\zeta$

number. Unfortunately, these formulae are hardly applicable to practical calculations, since they do not take into consideration additive effect of a big number of fibers forming a filtering partition in a fibrous mist collector. Obviously, their effect should be expressed by ratio $\mathrm{H} / \mathrm{d}_{\mathrm{F}}$ (where $\mathrm{H}$ - thickness of filtering partition, $\mathrm{m}$ ), then the dependency that describes the efficiency of a high-speed mist collector becomes:

$$
\eta=f\left(S t k ; \frac{H}{d_{F}}\right) .
$$

Expression (3) includes practically all the parameters characterizing the value of hydraulic resistance of a high-speed mist precipitator, usually it is calculated by the formula:

$$
\Delta P=\zeta \frac{v^{2} \cdot \rho_{g} \cdot H}{S_{0}^{2} \cdot d_{F}},
$$

where

$\Delta P$ - hydraulic resistance of mist collector, $\mathrm{Pa} ; \rho_{g}-$ density of gas flux density, $\mathrm{kg} / \mathrm{m}^{3} ; \mathrm{S}_{0}$ - free area (porosity), $\mathrm{m}^{2} / \mathrm{m}^{2}$.

Considering the above, it seems advisable to apply the method of physical analogy [5] to achieve calculated dependency of precipitation efficiency in high-speed filters - it is found exceptionally productive for elaboration of the method of calculation of mechanical (dry and wet) dust collectors [6], and to use the value of $\Delta \mathrm{P}$ as an analogue, this value could be easily found experimentally and by calculations. This physical analogy is, of course, defensible, because friction, that determines the value of hydraulic resistance, and precipitation of suspended particles due to inertial forces on a precipitating surface are caused by the same process of gas flow travel through a filtering layer.

Since disperse content of suspended particles at the inlet of gas-cleaning apparatus is in absolute majority of cases and fractional efficiency of inertial type equipment is practically always [4] under normally logarithmic law of distribution, the efficiency of mist collector could be calculated by probability integral $[4,7]$ :

$$
\eta=\frac{1}{2 \cdot \pi} \int_{-\infty}^{x} e^{-\frac{x^{2}}{2}} d x
$$

where

$$
x=\frac{\lg \left(d_{m} / d_{50}\right)}{\sqrt{\lg ^{2} \sigma_{p}+\lg ^{2} \sigma_{\eta}}},
$$

where

$d_{m}-$ median size of particles, $\mu \mathrm{m} ; d_{50}-$ diameter of suspended particles (drops), collected with the efficiency equal to $0,5 \mu \mathrm{m} ; \lg \sigma_{\mathrm{p}} ; \lg \sigma_{\eta}$ - standard logarithmic deviation in function of suspended particle (drop) distribution by size and fractional efficiency of dust and mist collector.

Hence, for calculation of high-speed mist collector using probability integral (its values depending on the values of " $x$ " are given in tables) there should be known a value of $d_{50}$ characterizing its facilities. Other parameters forming (6) should not be calculated: $d_{m}$ and $\lg \sigma_{\mathrm{p}}$ characterize disperse content of mist at the inlet of apparatus and should be known, the value of $\lg \sigma_{\eta}$ for high-speed mist collectors is 0,2 .

To generalize the experimental data achieved for high-speed filtration, dependency analogous to the formula used for calculation of scrubbers' efficiency was proposed [8]:

$$
d_{50}=1,044 \cdot \exp \left(-4,28 \cdot 10^{-4} \cdot \Delta P\right) .
$$

Formula (7) was achieved on the basis of experimental data in the limit of $0,2 \cdot 10^{3} \leq \Delta \mathrm{P} \leq 4 \cdot 10^{3} \mathrm{~Pa}$ under the density of collected particles $\rho_{p}=1000 \mathrm{~kg} / \mathrm{m}^{3}$.

To give a more precise definition of dependency (7) and to define the influence of compactness of collected particles (drops) some experimental studies were made using filtering partitions from various porous materials.

\section{Experimental assemblies}

Experimental investigation was performed on a laboratory setup (Fig 2) using oil mist.

The area of filter surface was changed using special insets from 0,014 to $0,0014 \mathrm{~m}^{2}$ that enabled tests under speed from 1 to $10 \mathrm{~m} / \mathrm{s}$ with constant gas flow through the filter equal to $100 \mathrm{~m}^{3} / \mathrm{h}$. Filtering felt was fixed by a tambour-type thrust-pressure plate.

A generator of polydisperse fog (mist) is a vessel with a conic cover on which there is a vertical pipe of about $1 \mathrm{~m}$ length. Four pneumatic jets (6) are installed in 


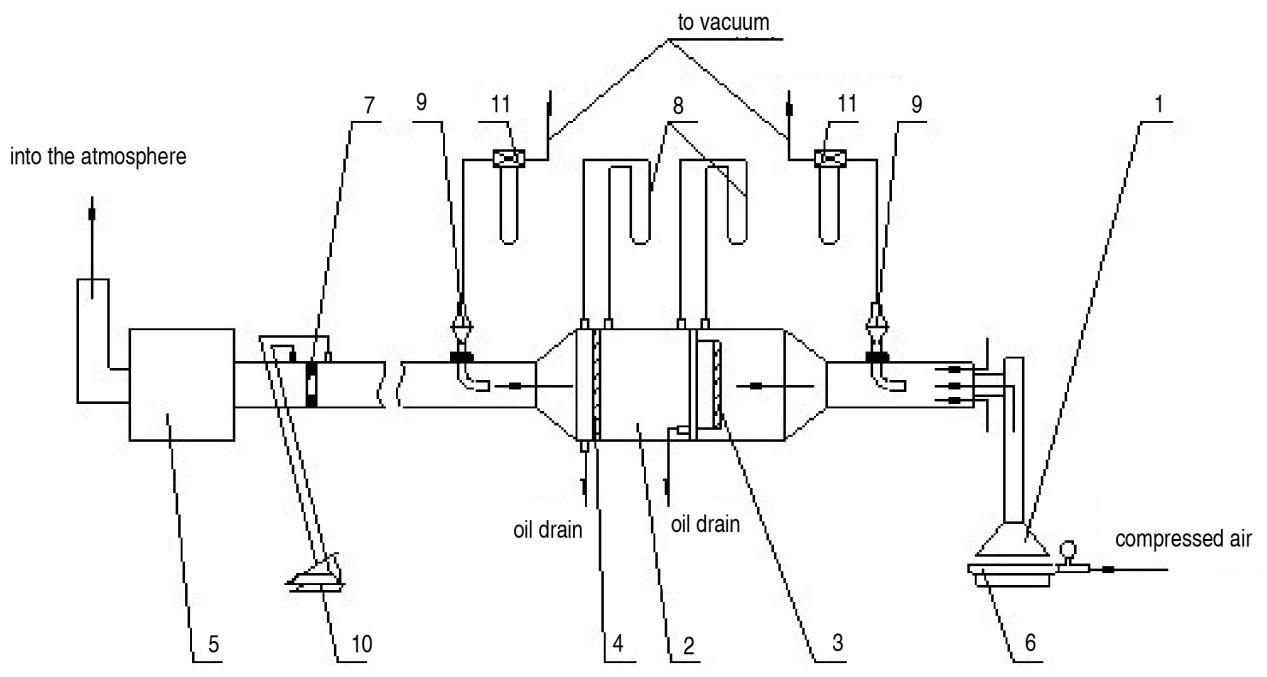

Fig 2. Scheme of experimental assembly: 1 - fog (mist) generator; 2 - filter; 3 - filter medium; 4 - mist extractor; 5 - ventilator; 6 - jets; 7 - diaphragm; 8 - U-type manometer; 9 - AFA type filter; 10 - micromanometer

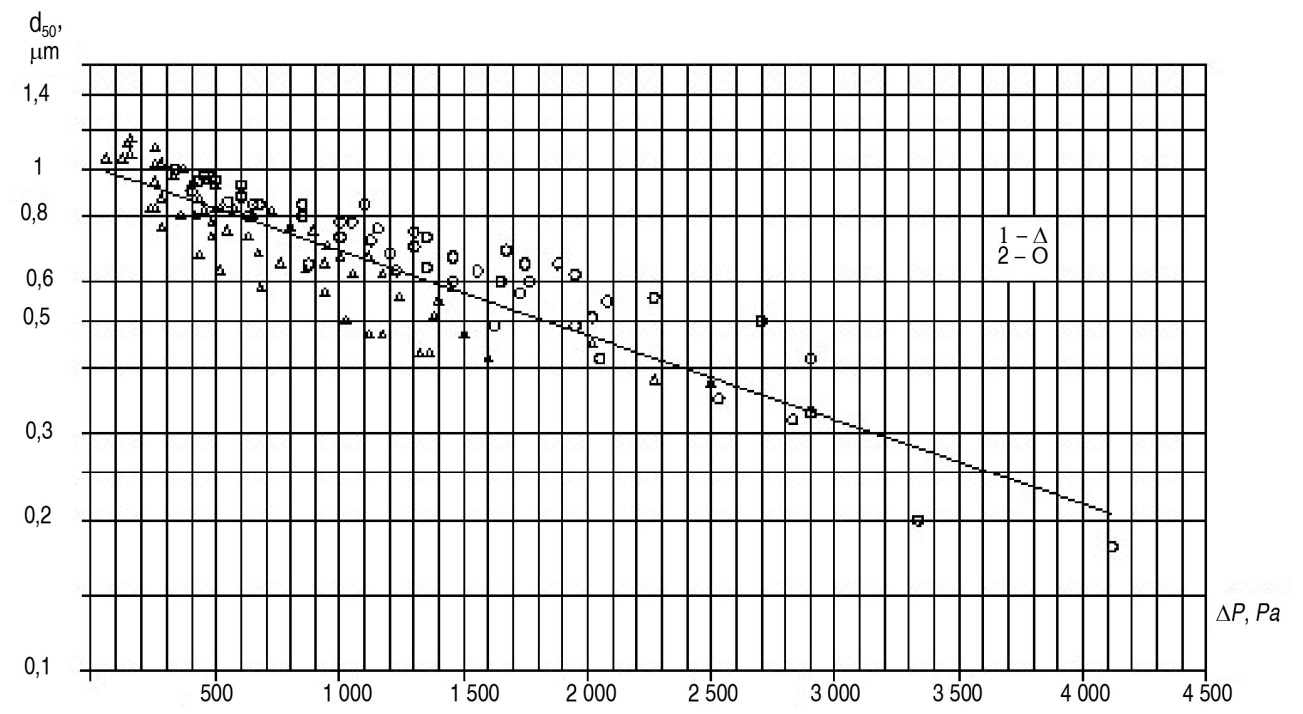

Fig 3. Summary of experimental data as a dependency of $\mathrm{d}_{50}$ on $\Delta P$ : 1 - experimental data; 2 - data from [8]

the bottom quadratic part of the vessel one by one from each side. Fog flows from jet to opposing wall which serves as a shield for striking large drops off. The pressure of air given into jets for oil spraying is kept constant and is equal to 0,2 $\mathrm{MPa}$. There were used a VM-1 type spindle oil (GOST (ГОCT) 7904-56) with the density of $0,885 \mathrm{~g} / \mathrm{cm}^{3}$.

\section{Investigation technique}

4.1. Measurements of the speed of volumetric gas (air) discharge, hydraulic resistance of the filter partition and mist collector were made according to actual state standards GOST (ГОСТ) 17.2.4.06-90 and 17.2.4.07-90.

4.2. Determination of mist drop concentration at the inlet and outlet of a filtration chamber was made using AFA-type membrane filters under the condition of isokineticity according to the state standard GOST R 5082095 (ГОСТ Р 50820-95).
4.3. Dispersity of mist (fog) drops at the inlet and outlet of a filtration chamber was made using jet separators (impactors) made by Karpov Physical Chemistry Research Institute with standard procedure.

Gas sampling to an impactor was made through a sampler according to isokineticity condition. Membrane filters were used as a substrate on stages of the impactor; at the final (finishing) stage there is an AFA-V-18 type membrane filter.

On the basis of these measurements in probabilisticlogarithmic frame of reference there were made integral curves of mist drop distribution by size allowing to determine median size of drops $\mathrm{d}_{\mathrm{m}}(\mu \mathrm{m})$ and distribution of distribution.

4.4. Calculation of efficiency of filtering partition $\eta$ was made using the formula:

$$
\eta=\frac{Z^{\prime}-Z^{\prime \prime}}{Z^{\prime}}
$$


where $Z^{\prime}, Z^{\prime \prime}$ - correspondingly, concentration of mist drops before and after filtration chamber, $\mathrm{g} / \mathrm{nm}^{3}$.

\section{Survey results}

As a filtering material there were used vinylplast and metal nets and felt of lavsan fibers.

Perforated vinylplast nets had various shape slots (circle and diamond). As a characteristic length 1 for net there was taken an equivalent inner diameter $d_{e}$ (varied from 2,35 to $3,0 \mathrm{~mm}$ ). Thickness of nets' layer varied from 5 to $12 \mathrm{~mm}$, free area - from 0,08 to $0,38 \mathrm{~m}^{2} / \mathrm{m}^{2}$.

Metal nets were made from round form wire with the diameter of 0,$05 ; 0,08$ and $0,23 \mathrm{~mm}$. Stacking distance of nets $\mathrm{H}$ was 20,50 and $90 \mathrm{~mm}$, porosity $0,98-$ $0,99 \mathrm{~m}^{2} / \mathrm{m}^{2}$.

Lavsan felt was made of fibers with the diameter of $60 \mu \mathrm{m}$, thickness of filtration layer was 8-10 mm.

Experimental data was processed by formula (6).

During investigation the value of $\mathrm{d}_{\mathrm{m}}$ was $1,3 \mu \mathrm{m}$, $\lg \sigma_{\mathrm{p}}=0,23$. The value of $\lg \sigma_{\eta}$ was assumed equal to $0,2[8]$.

The values of $d_{50}$ obtained by calculations are given in Fig 3, together with data from [8].

Processing of experimental data allowed to obtain empirical dependency for calculation of $\mathrm{d}_{50}$ in the range of values of $\Delta \mathrm{P}$ from 70 to $4120 \mathrm{~Pa}$. By analogy with formula used for calculation of the value of $d_{50}$ for wet dust separators [4], there were introduced a value of $\rho_{p}{ }^{-0,5}$, subsequent from the Stokes criterion and considering the density of particles collected in the mist extractor.

Obtained dependency is given by:

$$
d_{50}=32.21 \cdot \rho_{p}^{-0,5} \cdot \exp \left(-3.88 \cdot 10^{-4} \cdot \Delta P\right) .
$$

Root-sum-square uncertainty for calculation of $\mathrm{d}_{50}$ using formula (9) is $\sim 0,1 \mu \mathrm{m}$, then the confidence interval is $\pm 0,02$ under confidence probability $\alpha=95 \%$ (by Student) under the number of experimental points $n=109$.

Adequacy of dependency (9) was proved also by industrial tests collecting drops of phosphoric acid mist [9].

\section{Conclusions}

On the basis of experimental investigation there was achieved a refined formula for calculation of the value of $\mathrm{d}_{50}$ for high-speed mist extractors allowing to make engineering calculations of equipment efficiency considering the density of precipitated particles.

\section{References}

1. GUKHMAN, A. A. Application of similarity theory to studying of heat-and-mass transfer processes. Moscow: Vysshaya shkola, 1967. 304 p.

2. UZHOV, V. N.; WALDBERG, A.YU.; MYAGKOV, B. I.; RESHIDOV, I. K. Industrial gas cleaning from dust. Moscow: Khimiya, 1981. 392 p.

3. BÜRKHOLZ, A. Mist elimination. air pollution control. Pt IV / Ed. G. M. Bragg, W. Strauss. N. Y.: WileyIntersci. Publ., 1981. 187 p.

4. WALDBERG, A. YU.; ISYANOV, L. M.; YALAMOV, YU. I. Theoretic fundamentals of protection of atmosphere air from industrial aerosol pollution. SaintPetersburg, MP "NIIOGAZ-Filtr" SPbGTU RP, 1993. $235 \mathrm{p}$.

5. GUKHMAN, A. A. Introduction to similarity theory. Moscow: Vysshaya shkola, 1963. 256 p.

6. WALDBERG, A. YU.; KIRSANOVA, N. S. Method of calculation of efficiency of mechanical dust collectors on power consumption. Theoretical fundamentals of chemical technology (Теоретические основы химической технологии), 1992, Vol 26, No 1, p. 145.

7. Reference book on dust and ash collecting. Under editorship of A. A. Rusanov. Moscow: Energoatomizdat, 1983. $312 \mathrm{p}$.

8. WALDBERG, A. YU.; KRAYNOV, N. V.; SAVENKOV N. V., SAVITSKAYA, N. M. Calculation of efficiency of high-speed fibrous filters. Theoretical fundamentals of chemical technology (Теоретические основы химической технологии), 1994, Vol 28, No 2, p. 164-166.

9. MOSHKIN, A. A.; WALDBERG, A. YU; KAMENSHCHIKOV, I. G. Fibrous mist and spray collectors. Scientific and technical aspects of environmental protection (Научные и технические аспекты окружающей среды). Moscow: VINITI, 2000, No 1, p. 25-65.

\section{SUSPENDUOTU DALELIŲ INERTINIO NUSODINIMO DIDELIO GREIČIO PLUOŠINIUOSE FILTRUOSE EFEKTYVUMAS}

\section{A. Waldberg, S. Safonov}

Santrauka

Pateikta suspenduotų dalelių surinkimo didelio greičio pluoštiniu aerozolių filtru eksperimentinių tyrimų teorinė analizė ir rezultatai. Apibrèžta dominuojanti suspenduotų dalelių inercijos svarba didelio greičio surinktuvuose ir pasiūlytas skaičiavimo metodas, paremtas filtrų efektyvumo nustatymu integruojant tikimybes. Pateikta galimybe pritaikyti fiziniu aspektu analogišką metodą nustatant priklausomybę, išreiškiančią $d_{50}$ dalelių (dalelių, kurios surenkamos nurodytu režimu dirbančiame irenginyje $50 \%$ efektyvumu, skersmuo) vertes remiantis eksperimentiniais duomenimis. Pateiktas tyrimams ir testavimui skirto eksperimentinio agregato aprašymas ir rezultatų skaičiavimo metodai. Tyrimo rezultatai leido patobulinti formulę $d_{50}$ vertėms apskaičiuoti atsižvelgiant ị hidraulinį aparato pasipriešinimą ir surinktų dalelių tankị.

Reikšminiai žodžiai: pluoštinis filtras, automatinio modelio veika, inertinio nusodinimo efektyvumas. 


\section{ЭФФЕКТИВНОСТЬ ИНЕРЦИОННОГО ОСАЖДЕНИЯ ВЗВЕШЕННЫХ ЧАСТИЦ В ВЫСОКОСКО- РОСТНЫХ ВОЛОКНИСТЫХ ФИЛЬТРАХ}

\section{А. Ю. Вальдберг, С. Г. Сафонов}

\section{Р е $з$ ю м е}

Приводится теоретический анализ и результаты экспериментального исследования улавливания взвешенных частиц в высокоскоростных волокнистых туманоуловителях. Установлена доминирующая роль инерционного механизма осаждения взвешенных частиц в высокоскоростных туманоуловителях, и предложен метод расчета их эффективности с помощью интеграла вероятности. Показана возможность использования метода физической аналогии для вывода зависимости, определяющей на основании экспериментальных данных значения величины $\mathrm{d}_{50}$ (диаметр частиц, улавливаемых в аппарате при данном технологическом режиме его работы с эффективностью $50 \%$ ). Описана экспериментальная установка, на которой проводились исследования, приведены методики проведения опытов и оценки их результатов. Результаты исследований позволили получить уточненную формулу для расчета величины $d_{50}$ в зависимости от гидравлического сопротивления аппарата и плотности улавливаемых частиц.

Ключевые слова: волокнистый фильтр, автомодельный режим, эффективность инерционного осаждения.

Arnold WALDBERG. Dr Habil, Prof, Moscow State University of Environmental Engineering.

Dr Habil of Science (air pollution), Moscow Institute of Chemical Engineering (Russia), 1988. Doctor of Science (air pollution), Leningrad Institute of Technology of Lensovet (Russia), 1967. Employment: Professor of Moscow State University of Environmental Engineering (1999); Professor (1990); Deputy Director General and research officer in NIIOGAZ (1959). Publications: author of 6 monographs, 3 study-guides, 3 reference books, over 230 research papers and 36 inventions. Honorary awards and membership: professor (1990); honoured inventor of Russian Federation; full Member of Russian Ecological Academy. Research interests: air pollution, pollutant properties, pollution control equipment and methods.

Sergey SAFONOV. Engineer, doctoral student, Moscow State University of Environmental Engineering.

Employment: JSC “NIIOGAZ”, head of Construction Department. Research interests: air pollution, pollution control equipment and methods. 